\title{
UNDERSTANDING THE BEAST OF SEXUAL HARASSMENT IN THE WORKPLACE
}

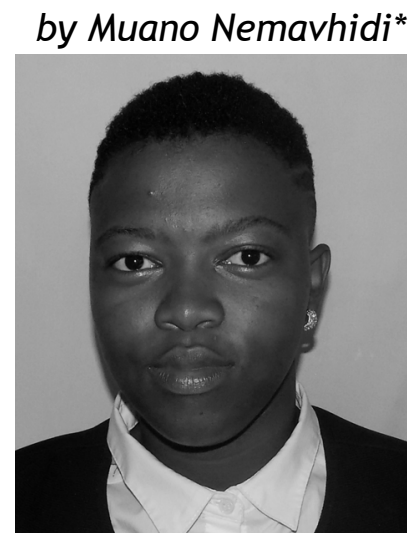

\section{Introduction}

The field of labour law is an increasingly expansive one; however, one standard aspect remains common to it. ${ }^{1}$ This inescapable requirement usually involves the interaction of persons in a work environment, whether on an employee-to-employee basis or employer-to-employee level. ${ }^{2}$ In these interactions, events may arise that constitute a breaching of what is acceptable workplace conduct. A common instance of this is sexual harassment. Sexual harassment as defined in section 3(1) of the Code of Good Practice on the Handling of Sexual Harassment Cases (the Code) refers to 'unwanted conduct of a sexual nature'. 3 It may be physical, verbal or non-verbal acts. At times sexual harassment may receive a nonchalant response that insinuates

* $\quad$ Final Year LLB student at the University of Venda, Limpopo, South Africa. The aim of this article is to address the prevalence of sexual harassment in the South African context. The article sheds light on the fact that sexual harassment need not only be physical acts and the fact that there are various forms of harassment. This article is shaped by the Year of the Woman, and that sexual harassment often results from an abuse of power.

1 A Ramsaroop \& $S$ Brijball-Parumasur 'The prevalence and nature of sexual harassment in the workplace: a model for early identification and effective management thereof' (2007) 33 (2) Suid-Afrikaanse Tydskrif Vir Bedryfslelkunde 25.

2 A Basson 'Sexual harassment in the workplace: An overview of developments' (2007) 18 (1) Stellenbosch Law Review 425.

3 Code of Good Practice on the Handling of Sexual Harassment Cases, Labour Relations Act item 3(1). 
the offended party somehow invited the sexual advances. ${ }^{4}$ In most cases, reasonable women do not complain about sexual harassment. ${ }^{5}$ This paper will seek to advance the perspective that this is not so and will do so by a critical analysis of various source materials. This is to the effect that the invalidity of this perspective will be critically exposed.

\section{The concept of sexual harassment in the South African context}

Sexual harassment refers to a pervasive vice permeating the workplace from the highest ranks of corporate bodies to those of ordinary worker on the street. ${ }^{6}$ As stated above, sexual harassment constitutes in the perpetration of unwelcome advances, demands for sexual favours, and other verbal or physical acts of a sexual sort. For example, lustful remarks, touching or sexual intercourse by any means. ${ }^{7}$ However, the question arises as to what variants of sexual harassment exist. The following section will discuss the forms of sexual harassment, seriatim.

\subsection{Forms of sexual harassment}

\subsubsection{Quid pro quo sexual harassment}

The term quid pro quo, in the literal sense, means a thing for a thing. ${ }^{8}$ The said higher-ranking person may do so by direct statements, suggestive remarks or actions. ${ }^{9}$ The Code of Good Practice on the Handling of Sexual Harassment Cases states that this can take place where a superior in a workplace makes a desirable thing, such as a promotion or raise, available to a subordinate worker in exchange for a favour of a sexual nature. Again, this includes where a superior influences the outcome of a dismissal hearing, employment process or disciplinary proceedings. ${ }^{10}$

4 LC Herbert 'Why don't "reasonable women” complain about sexual harassment' (2006) 82 (1) Indiana Law Journal 711.

$5 \quad$ Herbert ( $n$ 4) 47.

6 A Mukheibir \& L Ristow 'An overview of sexual harassment claims: Liability of the employer' (2006) 27 (2) Obiter 245.

7 As above.

8 FindLaw 'What is quid pro quo harassment?' https://employment.findlaw.com/ employment discrimination/what-is-quid-pro-quo-harassment.html (accessed 29 April 2018).

9 J Grogan Workplace law (2014) 132.

10 Code of Good Practice on the Handling of Sexual Harassment Cases, Labour Relations Act item 4 (1)(d). 


\subsubsection{Hostile environment sexual harassment}

This scenario relates to a situation whereby the person in a position of seniority by means of sexual advances or remarks makes the environment difficult to work in or otherwise uncomfortable for the other employee. ${ }^{11}$ This form of harassment need not threaten the employment prospects or livelihood of the employee. ${ }^{12}$ The Code makes specific reference to situations whereby an authority figure rewards those who submit to their advances but denies workplace advantages such as promotions to those who do not submit. The Code terms this as sexual favouritism. ${ }^{13}$ An example of this is the case of Christian $v$ Colliers Properties ${ }^{14}$ wherein employer A told worker B that if she would like to keep her job she must first spend a night with him. She was fired after declining to spend the night with A.

\subsubsection{Verbal sexual harassment}

Verbal sexual harassment usually consists in the making of uninvited innuendos, propositions, hints, sexual advances, remarks and even comments in passing. ${ }^{15}$ These do not need to be made in a serious tone, as even attempting to win someone's affections may constitute sexual harassment. The distinguishing feature is that such jokes have sexual undertones of a graphic nature. Verbal sexual harassment can extend to remarks about another person's body irrespective of whether they were made in the person's presence or 'to their face', so to speak. ${ }^{16}$ Another instance is prying into the sex life of another individual. ${ }^{17}$ This is illustrated in the case of Campbell Scientific Africa $\vee$ Simmers. ${ }^{18}$

\subsubsection{Non-verbal sexual harassment}

In stark contrast to verbal sexual harassment, non-verbal sexual harassment can happen in the absence of words. It can include undesired gestures, exposure of private parts, as well as exhibiting sexually offensive material. For example, where a female co-worker

11 The Advocates for Human Rights 'Sexual Harassment that Creates a Hostile Work Environment' http://www.stopvaw.org/sexual_harassment_that_creates_a_hos tile_work_environment (accessed 29 April 2018).

12 K Swisher What is sexual harassment? (1995) 48.

13 Code of Good Practice on the Handling of Sexual Harassment Cases, Labour Relations Act item 4 (2).

14 CAMP v Colliers Properties 2005 (5) BLLR 479 LC.

15 Basson (n 2) 427.

16 ML Boland Sexual Harassment in the Workplace (2005) 223.

17 Basson (n 2) 429; Code of Good Practice on the Handling of Sexual Harassment Cases, Labour Relations Act sec 4(1)(b).

18 Campbell Scientific Africa v Simmers \& Others (2016) 37 April ILJ 116 (LAC). See also: Sonja Grobler (nee Ensink) v Naspers Bpk and G Samuels (2004) 25 ILJ 439 (C). 
suggestively licks a lollipop in the presence of a co-worker, such conduct would constitute sexual harassment. ${ }^{19}$ In the case of NUMSA obo Mafuto v Duferco Steel Processing (Pty) Ltd, the Court classified sexually suggestive dancing towards a co-worker as sexual harassment. 20

\subsection{The prevalence of sexual harassment}

Sexual harassment is prevalent in all workplace contexts and largely affects more females than males. ${ }^{21}$ Moreover, it takes place often in the lives of young women who are new job entrants. This is in contrast to where males of any age are less likely to be victims of sexual harassment. This attributes to the vulnerability of women in both an economic and physical sense. ${ }^{22}$ Notwithstanding, reports of sexual harassment by males have been on the rise as males are encouraged to break the silence.

\subsection{Workplace attitudes towards sexual harassment}

Sexual harassment is largely classified as a minor issue by the male sex. This is according to several studies conducted by Bitton and Shaul. ${ }^{23}$ These studies reveal that most females have a wider view of the actions that when considered in totality constitute sexual harassment. The converse is true for males. Again, female workers have indicated a large degree of reluctance to report incidences of sexual harassment. Further, when the women do report they do so much later than would yield fruitful intervention. This, according to the study, contributes to the perception that women make things up with the intention of obtaining fame, money and other incentives. ${ }^{24}$

This worsens the plight of harassed women in that upon reporting the incidents they are perceived as unreasonable. Worse yet, they may be told that they brought it on themselves. ${ }^{25}$ This makes it harder for women to come forward. Such an attitude has been attributed to toxic masculinity, which renders women subservient to the demands of men. ${ }^{26}$ Notwithstanding this supposed cause, many authors

19 C Murray Gender and the new South African legal order (1994) 116.

20 NUMSA obo Mafuto $v$ Duferco Steel Processing (Pty) Ltd (MENT 21080).

21 R Le Roux Harassment in the workplace: Law, policies and processes (2010) 178.

22 Ramsaroop \& Brijball-Parumasur (n 1) 26.

23 MS Bitton \& DB Shaul 'Perceptions and attitudes to sexual harassment: An examination of sex differences and the sex composition of the harasser-target dyad' 201343 (1) Journal of Applied Social Psychology 2136.

24 As above.

25 N Smit \& D van der Nest 'When sisters are doing it for themselves: Sexual harassment claims in the workplace' 2004 3(1) Tydskrif vir die Suid-Afrikaanse Reg 534.

26 O Ladebo \& J Shopeju 'Sexual harassment: Perceptions and coping strategies among undergraduate students in Nigeria' 2004 36(3) Acta Academia 225. 
concede that the root causes of sexual harassment are unknown. However, the apparent ones range from ignorance, lack of restraint or malice. Thus, the prevailing attitude remains one of apathy towards victims. ${ }^{27}$

\section{The legislative framework relating to sexual harassment}

A complex network of statutory regulations regulates the issue of sexual harassment. Over the years, this network was made simple for ease of use as well as interpreted by the courts. It comprises of several pieces of legislation, which will be explored below.

\subsection{Code of Good Practice on the Handling of Sexual Harassment Cases ${ }^{28}$}

The Code of Good Practice on the Handling of Sexual Harassment Cases $^{29}$ makes notice of several variants of sexual harassment, one of which is the quid pro quo variant. It recognises it not only under the context of employers but also under even those employees who wield control over other employees. In terms of Item 4 of the Code, an employee does not need to be directly confronted with offensive behaviour, but may be harassed even where others receive rewards for agreeing to do sexual favours. In the same way, this is the case with the other variants of sexual harassment, namely; verbal sexual harassment, ${ }^{30}$ non-verbal sexual harassment, ${ }^{31}$ and hostile environment sexual environment. ${ }^{32}$ It is apparent that the Code has above all aimed to place in clear and broad terms the kinds of conduct that constitute sexual harassment.

Further, Item 5 of the Code requires the employer to take a policy stance that addresses sexual harassment. Again, it also requires the employer to take appropriate action. ${ }^{33}$ This intersects with the provisions of the Employment Equity Act, which renders employers liable who do not take steps to ensure its employees comply with the

27 JD Adams, MS Mabusela \& ET Dlamini 'Sexual harassment: The 'silent killer' of female students at the University of Ayoba in South Africa' 201327 (5) South African Journal of Higher Education 1149.

28 Code of Good Practice on the Handling of Sexual Harassment Cases, Labour Relations Act.

29 K Ross Women, rape \& violence in South Africa: Two preliminary studies (1994) 15.

30 See also (n 15).

31 See also (n 17).

32 See also (n 10).

33 L Khumalo, C Gwandame \& T Mayekiso 'Examining perceptions of sexual harassment among recent female graduates in the workplace.' 201544 (4) Africa Insight 107. 
Act. This indicates a combative policy stance against sexual harassment.

\subsection{Employment Equity Act $^{34}$}

In terms of the Employment Equity Act, employers are required to advance appropriate action when they know incidents of sexual harassment. ${ }^{35}$ This allows the complainant to sue the employer in terms of the Act where the employer fails to follow an appropriate course of action. In this regard, section 60(3) of the Act provides that 'if the employer fails to take all the necessary steps referred to in subsection(2), and it is proved that the employee has contravened the relevant provision, the employer must also be deemed to have contravened that provision. ${ }^{36}$ In effect, this places a duty on employers to address sexual harassment in the workplace. To fulfil this duty, an employer must, upon receipt of a complaint of sexual harassment, make consultations with all the affected persons and comply with the Act's provisions.

The exception to the above provision exists where the employer is able to show that they had taken reasonable steps towards compliance with the Act as to prevent an employee from contravening the Act. ${ }^{37}$ Noteworthy is that section 60 of the Act coincides with fulfilling the purpose of section 51 of the Act which is to protect employee rights. To that end, the Act also empowers the Minister, in terms of section 54, to issue a Code of Good Practice in respect of the Act. To this end, the Code on Sexual Harassment was issued. The Code defines and delineates the central aspects of sexual harassment in the workplace. Hence, where an employee faces unfair discrimination based on their sex, they may claim for damages in terms of section 50 of the Act.

\subsection{Labour Relations Act ${ }^{38}$}

In consideration of the Act, reference must be made to Section 138(6) of the Act. According to the section, the presiding officer must consider any Codes of good practice as issued by National Economic Development and Labor Council (NEDLAC) insofar as they are relevant to the matter before them. It is important to note that the NEDLAC was empowered to do so in terms of section 203 of the Act. This means the Code is always considered in matters involving sexual 
harassment. $^{39}$ In this case, said Code is the 2005 Code of Good Practice on the Handling of Sexual Harassment Cases.

The Act empowers employees to seek a remedy using the internal structures of the workplace. In the event that a party to the sexual harassment dispute is unsatisfied with that outcome, they may make use of section 135 of the Act. The section provides that the unsatisfied party may approach the Commission for Conciliation Mediation and Arbitration (CCMA) within 30 days of the dispute. ${ }^{40}$

In this regard, where an employee lost their job due to sexual harassment. The issue then becomes whether it was due to unfair discrimination based on sex or constructive dismissal. ${ }^{41}$ The latter occurs where the employee leaves due to the harassment and is addressed by section 186(1)(e) read with section 187(1)(f). If successful, the employee receives compensation. Alternatively, they may claim damages for unfair discrimination in terms of the Employment Equity Act. However, these remedies do not need to be used individually but may be used in combination.

\section{Judicial analysis of the sexual harassment dilemma}

The sexual harassment dilemma is often addressed by the courts against many factual backdrops and economic contexts. I shall critically analyse some of the prominent cases by reference to case law.

\subsection{University of Venda $v$ Maluleke and Others ${ }^{42}$}

\subsubsection{Facts}

In this matter, the applicant (the University of Venda) sought review of a decision by the Commission for Conciliation Mediation and Arbitration (CCMA) made in favour of the first respondent ( $\mathrm{Mr}$ Maluleke). The factual matrix was that the first respondent allegedly made sexual advances towards three of his female students. Said students reported the advances through the relevant structures.

As above.

Khumalo (n 33).

Basson (n 3 above) 443.

42 University of Venda $v$ Maluleke and Others (2017) 38 ILJ 1376 (LC) (28 February 2017). 


\subsubsection{In the Court a Quo}

Mr Maluleke (the first respondent) made an application in the High Court seeking that a review is made of the outcome of a 'CCMA' arbitration hearing which gave its order in favour of the University of Venda (the applicant). In assessing the matter, the application was unsuccessful.

\subsubsection{On review}

After determining the reviewability of the matter, Snyman AJ began tackling the matter from a factual perspective. From this view, he concluded that the oral testimony of the three complainants gives rise to a probability that the incidents took place as alleged by the complainants and not by the respondent. On the facts, the learned judge pointed out that the conduct of the respondent is consistent with the definition of sexual harassment as per the university's own policy documents. Therefore, he was to be subject to the sanction imposed therein, which would be both substantively and procedurally fair.

The Court cited the cases of SA Metal Group (Pty) Ltd $v$ Commission for Conciliation, Mediation and Arbitration and Others. ${ }^{43}$ As well as of Maepe $v$ Commission for Conciliation, Mediation and Arbitration and Another ${ }^{44}$ in respect of support of the use of the 2005 Code of Good Practice on the Handling of Sexual Harassment Cases as the yardstick for what constitutes sexual harassment as per item 4 . The Court held in favour of the applicant.

\subsection{Kok $v$ Commission for Conciliation, Mediation and Arbitration and Others ${ }^{45}$}

\subsubsection{Facts}

The applicant (Kok) had affections for the complainant who the Court referred to as ' $\mathrm{T}$ ' (a cleaner employed by a third party) and tried to win her over romantically. He was unsuccessful. He, on a later date, fondled 'T's' breasts, buttocks and genitals. He stated that he could not restrain his passion further and flashed his genitals to her. He then forced her to hold them under threat of dismissal if she did not comply. On another occasion, he caused himself to ejaculate on her.

43 SA Metal Group (Pty) Ltd $v$ Commission for Conciliation Mediation and Arbitration and Others (2014) 35 ILJ 2848 (LC) (15 April 2014).

44 Maepe $v$ Commission for Conciliation, Mediation and Arbitration and Another (2018) 39 ILJ 1029 (LAC) (25 January 2018).

45 Kok v Commission for Conciliation Mediation and Arbitration and Others [2015] JOL 32888 (LC). 
Again, he had said he could not restrain himself anymore. Another incident similar to the previous two ensued. The difference this time, however, was ' $T$ ' now reported the matter.

Kok was summoned to a disciplinary hearing by his employer (ABSA) to face charges of sexual harassment in respect of ' $T$ '. At the said hearing, the court found Kok guilty and subsequently dismissed on a single month's notice.

\subsubsection{In the Commission for Conciliation Mediation and Arbitration}

Upon this outcome, Kok went to the CCMA raising the issue of an unfair dismissal. The finding was that due to the probabilities weighing in favour of the truthfulness of the complainant's version, it is fair to conclude that the sexual harassment did indeed take place as alleged. Considering credibility, there was no incoherence in the statements of the complainant at any stage in the proceedings.

\subsubsection{The Labour Court}

The first leg of the Court's inquiry was the 'reviewability' of the CCMA's decision. It found that in line with the principles set out in Sidumo and Another $v$ Rustenburg Platinum Mines Ltd and Others ${ }^{46}$ that dictate reasonableness as a suitable ground of review. In this regard, the applicant pointed towards the credibility finding of the complainant's evidence and the arbitrator's alleged misconduct. On the record of proceedings, the Court made a finding that the grounds had no footing on facts and upheld the finding of the CCMA.

\subsection{Campbell Scientific Africa (Pty) Ltd $v$ Simmers and Others $^{47}$}

\subsubsection{Facts}

The case concerns an incident of alleged sexual harassment perpetrated by the respondent ('Simmers'), an employee of the appellant (Campbell Scientific Africa). It transpired that the respondent had to undertake a work-related trip to Botswana with one Ms CM (the complainant); whom did another company employ. During the trip, Simmers inquired as to whether the complainant would like a lover for the night, she refused. He further asked her relationship status which she clarified that she was in a committed

46 Sidumo and Another $v$ Rustenburg Platinum Mines Ltd and Others (2007) 28 ILJ 2405 (CC).

47 See also (n 18). 
relationship. Before bed, he informed her that he would be in a nearby room should she change her mind. She later informed management of her discomfort resulting from the behaviour. Simmers was called to a disciplinary hearing on charges of sexual harassment, misconduct and bringing the appellant's image into disrepute. This led to his dismissal.

\subsubsection{In the Commission for Conciliation Mediation and Arbitration (CCMA)}

Simmers was unhappy with this outcome and sought relief from the CCMA. The arbitration yielded the result that the decision of the hearing was correct. His behaviour was seen, by the arbitrator, to constitute sexual harassment and inappropriate for the context. The dismissal was, in this circumstance, an appropriate sanction. ${ }^{48}$

\subsubsection{In the Labour Court}

The Court primarily considered the question of whether Simmers inquiry amounted to sexual attention or sexual harassment. Steenkamp J noted that the Code's guidelines on when sexual attention becomes sexual harassment were not breached. This was insofar as Simmers had not persisted in his conduct nor breached the threshold for his single incident to be considered sexual harassment. Again, he had done so in ambition and not anticipation. Notwithstanding, the fact that Ms. CM walked away to show her disapproval of his actions. Thus, his conduct did not warrant a dismissal. 49

\subsubsection{In the Labour Appeal Court ${ }^{50}$}

Here, the Court first considered the foundational values of the Constitution, which are; human dignity, achieving equality within a non-racial and non-sexist society under the rule of law. This is set against the aim of achieving substantive equality. Thus, sexual harassment is an infringement of those rights as per section 6(3) of the Employment Equity Act as well as both the old (1998) and the new (2005) Code of Good Practice on the Handling of Sexual Harassment Cases.

It further noted that sexual harassment protections encompass not only employees but also all those within the workplace context. 65.

49 Simmers v Campbell Scientific Africa (2014) 35 ILJ 2866 (LC) (9 May 2014).

50 See also (n 18). 
In this regard, it pointed out that Simmers' conduct constituted sexual harassment as defined. It further happened where he had a power advantage over the complainant. To this effect, the Court cited with approval the cases of SA Broadcasting Corporation Ltd $v$ Grogan NO and Another ${ }^{51}$ as well as Gaga v Anglo Platinum Ltd and Others. ${ }^{52}$ The principles expounded therein centred on how unequal power relations are assistive in the inquiry on what constitutes sexual harassment. Therefore, in light of the circumstances the dismissal was substantively fair. Further, the sanction imposed was appropriate, as there is no tangible probability of restoring the employment relationship. The appeal was upheld.

Concerning the above case, it is expedient to make mention of Botes' commentary. She contends that the central aspect to prove is whether sexual harassment did take place. ${ }^{53}$ Once that is established, the inquiry then turns towards the appropriate measure to take. This applies in respect of the remedies available to the complainant and the sanctions imposed on the 'guilty party'. This is informed by the weight of the misconduct. ${ }^{54}$ This in turn sums up the common thread of sexual harassment cases.

\subsection{Grey v Education Labour Relations Council and Others ${ }^{55}$}

\subsubsection{Facts}

In this matter, an educator referred to as Grey (the appellant) was a teacher at a certain high school. During the course of his employment there, he began an intimate relationship with a seventeen (17) year old pupil. After the hearing at the school, he was dismissed on that basis. He later sought recourse at the CCMA where the arbitrator found that the dismissal was fair only in the substantive sense and not in the procedural sense. This was due to the disciplinary hearing chairperson showing bias against the appellant. The appellant again went further to the Labour Court where the application for review was dismissed. Still not satisfied, Grey applied for leave to appeal to the Labour Appeal Court, which was granted.

51 SA Broadcasting Corporation Ltd v Grogan NO and Another (2006) 27 ILJ 1519 (LC).

52 Gaga $v$ Anglo Platinum Ltd and Others [2012] 3 BLLR 285 (LAC).

53 A Botes 'Sexual harassment as a ground for dismissal: a critical evaluation of the labour and labour appeal courts' decisions in Simmers $v$ Campbell Scientific Africa 2017 (4) TSAR 761.

54 As above.

55 Grey $\vee$ Education Labour Relations Council and Others (2015) 36 ILJ 2802 (LAC) (23 October 2015). 


\subsubsection{In the Labour Appeal Court}

The Court considered the provisions of section 17(1)(c) of the Employment of Educators Act, ${ }^{56}$ which prohibits relationships between educators and learners. On the facts, the Court found that the incidents described by the learner are the most probable version of events and do constitute sexual harassment. The appellant's version was found wanting in credibility, and the inconsistencies present in the learner's version are most likely attributed to the appellant's attempts to influence her testimony. For the purposes of reconciling the conflicting versions, the Court agreed with the arbitrator's use of the approach used in the case of SFW Group Ltd and Another $v$ Martell et Cie and Others ${ }^{57}$

Therefore, as in the Labour Court, dismissal was found to be an appropriate sanction. However, the way in which it was done was substantively fair but not procedurally fair. The appeal was therefore dismissed.

\section{Commentary}

The preceding discussion illustrates through case law how most of the incidences of sexual harassment are not provoked by the actions of the victims, most of whom are female. Instead, the perpetrators initiate and carry out these actions. These perpetrators, once caught, make arguments that portray the victims as either willing participants or seek to discredit the reports of the victim altogether. In so saying, if their arguments were heeded without regard to the rest of the evidence, the sexual harassment would be 'swept under the rug', so to speak. Drawing particular attention to the Grey case, it is notable that the perpetrator sought to disturb the evidence that the complainant gave.

This is not to say that every incidence that takes place portrays the harasser as a villain. Instead, this is to point out the general attitude society has towards reports of sexual harassment. This is in so far as, the woman herself is vilified to seem as though she plotted the whole incident.

\section{Conclusion}

Having considered the above, it is quite apparent that despite the efforts of our legal system sexual harassment remains a pervasive foe. It emanates through even the highest echelons of the work

57 SFW Group Ltd and Another v Martell et Cie and Others 2003 (1) SA 11 (SCA). 
environment. The legislative framework pertaining to labour law has indeed grown and evolved in keeping with the dynamic nature of sexual harassment with respect to the way in which it manifests itself. In Motsamai v Everite Building Products (Pty) Ltd it was said that:

Sexual harassment is the most heinous conduct that plagues the workplace; ... it undermines the dignity, integrity and self-worth of the employee harassed ... goes to the root of one's being and must, therefore, be viewed from the point of view of a victim. ${ }^{58}$

Therefore, sexual harassment is normally not provoked by any inherent characteristics of the female sex. Instead, it is a reflection of societal attitudes of misogyny saturating the workplace.

58 Motsamai v Everite Building Products (Pty) Ltd [2011] 2 BLLR 144 (LAC) (4 June 2010). 